\title{
Soil solarization as a sustainable solution to control tomato Pseudomonads infections in greenhouses
}

\author{
Ivana Castello $^{1} \cdot$ Alessandro D'Emilio $^{1} \cdot$ Michael Raviv $^{2} \cdot{\text { Alessandro } \text { Vitale }^{1}}^{(D)}$
}

Accepted: 10 October 2017 /Published online: 2 November 2017

(C) INRA and Springer-Verlag France SAS 2017

\begin{abstract}
The reduction or phase-out of soil fumigants according to European directives has led to a re-evaluation of sustainable heat-based techniques and exploiting solar energy, e.g., solarization that was used successfully for the eradication of fungi, weeds, and nematodes. Since the beginning of the current century, bacterial infections caused by phytopathogenic Pseudomonads have been increasingly reported as threat for many horticultural crops worldwide. Nowadays, this disease represents a limiting factor for the tomato production in the Mediterranean basin under greenhouse conditions. Therefore, we tested the effects of soil solarization in controlling natural infections caused by Pseudomonas fluorescens on tomato cultivations in Sicily (south Italy) from 2010 to 2013 under different greenhouse conditions, i.e., with lateral openings uncovered or kept closed. Four experiments were performed under both wooden-concrete and steel-made greenhouses to compare the performances of innovative and traditional films alone or combined with other control measures (only in partially opened greenhouses) against tomato bacterial infections. All solarization treatments were effective in controlling phytopathogenic pseudomonads except for one carried out in a multi-span steel greenhouse with the side openings kept raised. Tested greenhouse covering and mulching films increased soil temperature up to $9.6^{\circ} \mathrm{C}$ at $15 \mathrm{~cm}$ and $7.7^{\circ} \mathrm{C}$ at $30 \mathrm{~cm}$, respectively, if compared to bare plots. Moreover, solarization treatments proved effective in controlling bacterial
\end{abstract}

Alessandro Vitale

alevital@unict.it

1 Department of Agriculture, Food and Environment, University of Catania, S. Sofia 100, 95123 Catania, Italy

2 Institute of Plant Sciences, Agricultural Research Organization, Newe Ya'ar Research Center, Ramat Yishay, Israel infections (up to about $90 \%$ reduction of disease amount) and in increasing yield up to $45 \%$ relative to the bare plots. Among tested films, EVA showed the best performances both in reducing bacterial infections and increasing tomato yield, innovative polyamide VIF and smoky gray were very promising films while green coextruded could be considered a very attractive film since it can be left on after solarization process as mulch for tomato transplanting. This study shows for the first time the feasibility and sustainability of soil solarization performed with innovative materials in managing tomato bacterial diseases in greenhouse.

Keywords Pseudomonads infections · Mulching film · Soil solarization $\cdot$ Greenhouse covering $\cdot$ Tomato yield

\section{Introduction}

Tomato (Solanum lycopersicum L.) is one of the most important crops widely cultivated in Italy under protected environment systems with 7158 ha of area harvested and a production of 518,292 tons in 2016 (ISTAT 2016). Approximately 35\% of this production is mainly concentrated in Ragusa, Syracuse, and Caltanissetta provinces, representing the Sicilian tomato production district, one among the most important European area. This area also includes "Tomato of Pachino" production granted by European Community with Protected Geographical Indication (PGI) label (Dossier IT/PGI/0005/0153-2003).

In the last decade, the phasing-out of methyl bromide and severe European restrictions for the use of alternative fumigants led to a substantial lack of effective chemical means for soil disinfection in Italy. The increasing researches to set up integrated pest management (IPM) plans are often time-consuming, and variable data involved in response to 
phytopathological issues emphasize how changes in climatic conditions will have particularly strong effects on new plant diseases occurrence and its development over time (Savary et al. 2011; Garrett et al. 2013; Bebber 2015). On the other hand, the application of nonchemical control measures alone (i.e., agronomic, biological, and genetic) against soilborne plant pathogens have a narrow spectrum of activity and/or lack of consistency if compared with classic soil fumigation (Gamliel et al. 2000; Chellemi 2002; Gullino et al. 2003; Vitale et al. 2014). In detail, suitable agro-meteorological measures for protected conditions for tomato crop (up to two or more crop cycles/year) coupled with global warming (Barredo et al. 2016) led to an increase of emerging bacterial diseases for some horticultural crops as well as phytopathogenic pseudomonads (Molan and Ibrahim 2007; Dimartino et al. 2011; Zhang et al. 2014; Zhang et al. 2016). Currently, fluorescent Pseudomonads may represent a threat for tomato production, being causal agents of widespread leaf chlorosis and necrosis and stem discoloration of plants (Fig. 1) under protected crop systems in the Mediterranean basin (Saygili et al. 2004; Molan and Ibrahim 2007; Dimartino et al. 2011). High temperature and relative humidity values followed by other biotic stresses (e.g., high salinity conditions) inside greenhouse may favor the occurrence of disease infections (Dimartino et al. 2011; Lo Cantore and Iacobellis 2002) since these bacteria are well distributed into soil and plant rhizosphere as also opportunistic microorganisms (Bradbury 1986). Among nonchemical alternatives, soil solarization has already proven effective in the management of many soilborne fungal pathogens, weeds and other pests (Gamliel and Katan 2012; Melero-Vara et al. 2012; Vitale et al. 2011; Vitale et al. 2013b; Mauro et al. 2015). In addition, thermal and biological effects of this technique may be predicted over time and modulated by mean of innovative materials (Fig. 1) used for soil solarization in relation to targeted pathogen (Cascone et al. 2008; D'Emilio et al. 2012; Vitale et al. 2013a).

In this regard, the main objectives of this study were (i) to evaluate the efficacy of soil solarization in controlling natural infections on tomato caused by phytopathogenic pseudomonads and (ii) to compare the performances of tested materials both used for greenhouse covering and soil mulching against natural infections caused by Pseudomonas fluorescens on tomato plants. Differences in treatment performances were also reported between trials carried out in wood-concrete and in the multi-span steel greenhouses (Fig. 1).
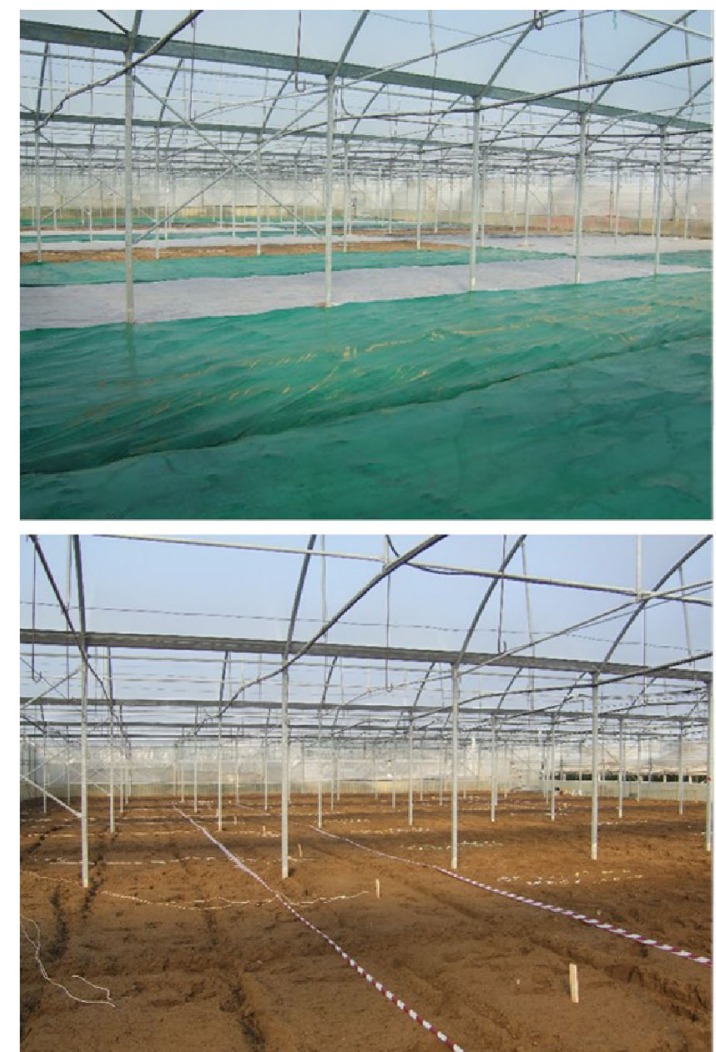

Fig. 1 Upper panel, Soil solarization performed in a multi-span steelframed greenhouse closed (on the left) and in a multi-span woodenconcrete greenhouse with lateral openings kept raised (on the right).
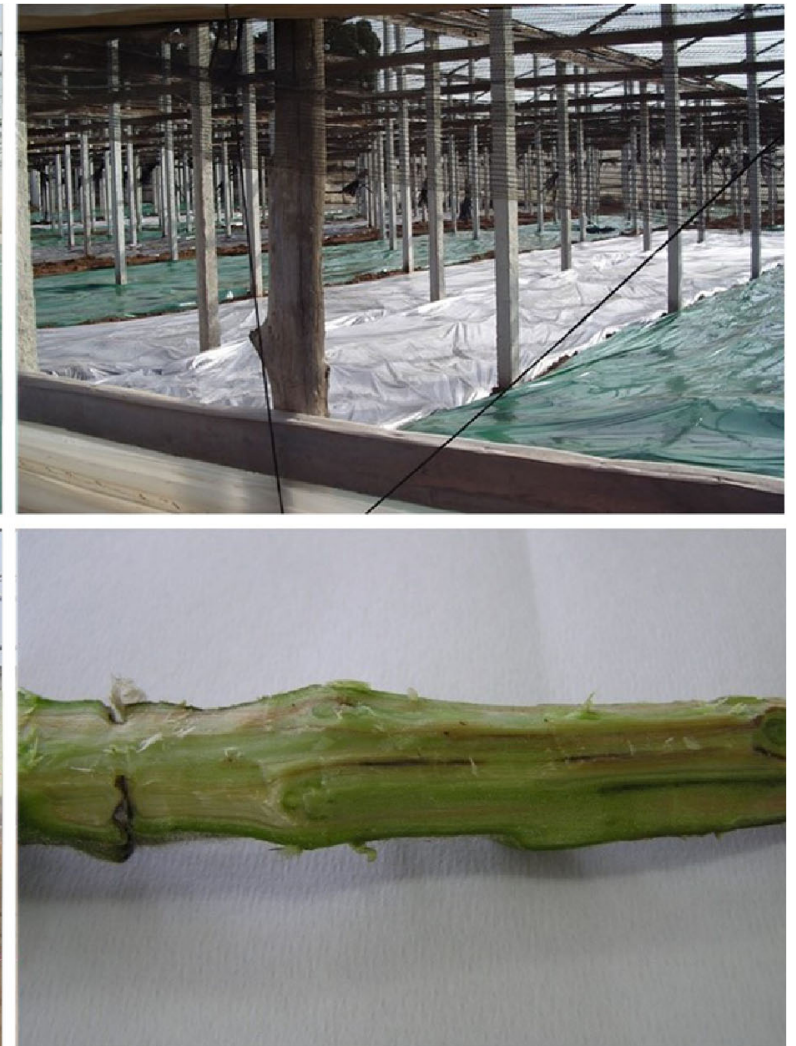

Lower panel, Probe placement for soil temperature measurement (on the left) and vascular infection caused by Pseudomonas fluorescent on tomato stem (on the right) 


\section{Materials and methods}

\subsection{Solarization sites}

Four experiments were carried out during three cropping seasons 2010/2011 (I), 2011/2012 (II), and 2012/2013 (III and IV), respectively in three unheated greenhouses located in the most representative area of tomato production in southeastern Sicily, Italy. Experiments I and II were conducted in two commercial farms located at Vittoria $\left(36^{\circ} 54^{\prime} 49.02^{\prime \prime} \mathrm{N}, 14^{\circ} 26^{\prime}\right.$ $32.10^{\prime \prime}$ E-altitude $70 \mathrm{~m}$ a.s.1.) and Santa Croce Camerina ( $36^{\circ}$ $47^{\prime} 46.20^{\prime \prime} \mathrm{N}, 14^{\circ} 29^{\prime} 53.46^{\prime \prime}$ E-altitude $23 \mathrm{~m}$ a.s.l.), respectively, in Ragusa province. Experiment III and IV were both carried out in twin greenhouses in a commercial farm located at Gela $\left(37^{\circ} 00^{\prime} 28.04^{\prime \prime} \mathrm{N}, 14^{\circ} 20^{\prime} 55.46^{\prime \prime} \mathrm{E} ; 37^{\circ} 00^{\prime} 24.24^{\prime \prime} \mathrm{N}\right.$, $14^{\circ} 20^{\prime} 49.68^{\prime \prime}$ E-altitude $7 \mathrm{~m}$ a.s.1.), in Caltanissetta province.

All of the experimental sites were naturally infested with bacteria and had a history of severe symptoms of vascular and pith discoloration caused by fluorescent Pseudomonads on tomato (Dimartino et al. 2011). In addition, these farms were frequently sampled for a monitoring of these bacteria representing a serious threat for tomato production.

\subsection{Experimental designs, solarization, and tomato planting}

In all experiments, soil was leveled and irrigated up to field capacity $\left(40\right.$ to $501 \mathrm{~m}^{-2}$ ) before soil solarization. Throughout the solarization period, no additional irrigation was supplied and the greenhouses were maintained with lateral openings kept partially raised in experiments I and II, whereas they were kept closed in experiments III and IV (Fig. 1). The solarization period ranged about from 8 to 10 weeks.

During experiments, soil temperature was measured at 15 and $30 \mathrm{~cm}$ depth in two plots of each treatment in all greenhouses. Two platinum thermoresistance probes (PT100, model 108; Campbell Scientific Ltd., Shepshed, Lougborough, UK) were used for each depth. After the placement of probes (Fig. 1), the film sheets were laid on the soil surface and their edges were buried up to $30 \mathrm{~cm}$ depth. Furthermore, combined air temperature and relative humidity sensors (model RH1; Environmental Measurements Ltd., Sunderland, UK) and pyranometers (model MS-102; EKO Instruments Co., Ltd., Tokyo, Japan) for the measurements every $15 \mathrm{~s}$ and recording the corresponding average values every $30 \mathrm{~min}$.

In all experiments, treatments were arranged in a randomized complete block design (RCBD) with three replicates (plots) each constituted by an adequate number of plants taken from the central portion of plots. After soil solarization, the mulching films, except the ones designed to be kept on soil during the cropping cycle, were removed and replaced with a conventional $50-\mu \mathrm{m}$-thick black polyethylene (PE) film (SI.SAC. S.p.a., Ragusa, Italy). The same PE film was used to mulch all the plots that were kept uncovered during solarization period. The tomato transplanting was always performed in double rows along the middle axis of each plot.

Experiment I This trial was carried out inside a $68.4 \times 32.0 \mathrm{~m}$ multi-span wooden-concrete greenhouse with the longitudinal axis oriented in the NE-SW direction. The span width was $7.60 \mathrm{~m}$, the ridge height was $3.6 \mathrm{~m}$, and the gutter height was $2.6 \mathrm{~m}$. The greenhouse was equipped with continuous vents along the front walls, $1.30 \mathrm{~m}$ high at about $70 \mathrm{~cm}$ from the ground that were left open during the whole treatment. The greenhouse was covered by a $150-\mu \mathrm{m}$-thick ethylene-vinylacetate (EVA) film (SI.SAC.) prior to soil solarization. The soil texture consisted of $88.2 \%$ sand, $6.2 \%$ clay, and $5.6 \%$ silt, with a $\mathrm{pH}$ of 8.0 , electrical conductivity of $1.6 \mathrm{mS} \mathrm{cm}^{-1}$, and an organic matter content of $3.2 \%$ due to high rates of mature cow manure $\left(100 \mathrm{~m}^{3 /} \mathrm{ha}\right)$ applied to soil prior tomato transplanting. Seven different treatments consisted of the following: (i) untreated control, (ii) solarization with a $25-\mu \mathrm{m}-$ thick clear EVA film (Agriplast S.r.l. Ragusa, Italia), (iii) solarization with a $25-\mu \mathrm{m}$-thick green coextruded EVA film (Agriplast), (iv) solarization with the green film after application of a commercial Brassica pellet (Biofence, Triumph Italia S.p.a.) at rate of $150 \mathrm{~g} \mathrm{~m}^{-2}$, (v) solarization with the green film and application of Trichoderma harzianum Rifai T22 (Trianum-G, Koppert Italia) at rate of $10 \mathrm{~kg} \mathrm{ha}^{-1} 10$ days prior to transplanting, (vi) solarization with the green film after application of $B$. juncea hand-made pellet at rate of $50 \mathrm{~g} \mathrm{~m}^{-2}$, and (vii) solarization with a $55-\mu \mathrm{m}$-thick smoky gray photo-selective LDPE film (Agriplast), obtained with addition of lampblack. The green coextruded EVA film was designed to be kept on soil after the end of soil solarization for the entire cropping season.

The solarization treatments were arranged in a RCBD with three replications. Each experimental plot was $3.8 \times 16 \mathrm{~m}$. Solarization treatments lasted from 8 July to 12 September 2010 (66 days). On 23 September 2010, indeterminate tomato seedlings of mini plum cultivar Piccadilly (Syngenta) were transplanted in each plot. Bacterial disease incidence and symptoms severity were evaluated on plant samples collected on 13 June 2011, at the end of the cropping season.

Experiment II This trial was carried out in a $64.0 \times 13.5 \mathrm{~m}$ multi-span steel-framed tunnel greenhouse. The ridge axis was oriented in NW-SE direction. The span width was $8.0 \mathrm{~m}$, the ridge height was $2.9 \mathrm{~m}$, and the gutter height was $4.6 \mathrm{~m}$. The greenhouse was equipped with continuous vents along the front walls, $1.90 \mathrm{~m}$ high at about $70 \mathrm{~cm}$ from the ground and that were left open during the whole treatment. The greenhouse was covered by a $150-\mu \mathrm{m}$-thick ethylene-vinyl-acetate (EVA) film (SI.SAC.) at the beginning of the trial. The soil texture consisted of $87.3 \%$ sand, $6.4 \%$ clay, and $6.3 \%$ silt, with a $\mathrm{pH}$ of 8.1 , electrical conductivity of $1.5 \mathrm{mS} \mathrm{cm}$ 
and an organic matter content of $3.8 \%$ following incorporation of high rates of cow manure into soil. Seven different treatments were tested: (i) untreated control, (ii) solarization with a 25- $\mu \mathrm{m}$-thick clear EVA film (Agriplast), (iii) solarization with EVA film after metam sodium application (MS, $178.5 \mathrm{~g}$ a.i. $\mathrm{ha}^{-1}$, Divapan 51, Taminco Italia S.r.1.) with pole injectors to soil, (iv) solarization with EVA film after metam potassium application (MK, $204 \mathrm{~g}$ a.i. ha $^{-1}$, Tamifum-K, Taminco Italia) applied with pole injectors to soil, (v) solarization with EVA film after application of Biofence (Triumph Italia) at rate of $150 \mathrm{~g} \mathrm{~m}^{-2}$, (vi) solarization with EVA film and application of Trichoderma harzianum Rifai T22 (Trianum-G, Koppert Italia) at rate of $10 \mathrm{~kg} \mathrm{ha}^{-1} 10$ days prior to transplanting, and (vii) solarization with a $25-\mu \mathrm{m}$-thick green coextruded film (Agriplast).

The solarization treatments were arranged in a RCBD with three replications. Each experimental plot was $4 \times 6.7 \mathrm{~m}$. Solarization treatments lasted from 21 June to 29 August 2011 (69 days). Following solarization treatments on 15 October 2011 indeterminate tomato seedlings cultivar Ikram (Syngenta) were transplanted in each plot. Disease incidence and severity of bacterial infections were evaluated on plant samples collected on 18 June 2012 at the end of the cropping season.

Experiments III and IV These trials were carried out inside two twin multi-span steel-framed tunnel greenhouses. The size of each greenhouse was $45.0 \times 29.5 \mathrm{~m}$ and the ridge axis was N-S oriented. The span width was $8.0 \mathrm{~m}$, the ridge height was $2.9 \mathrm{~m}$, and the gutter height was $4.6 \mathrm{~m}$. Both greenhouses were kept closed during the whole treatment. The difference in the protocol concerned solely the greenhouse cover: in experiment III the cover was a 150- $\mu$ m-thick EVA (Agriplast), whereas in experiment IV the cover was a 60 - $\mu$ m-thick polyamide-based film (Agriplast). The soil textures consisted of $55.2 \%$ sand, $39.2 \%$ clay, and $5.6 \%$ silt with a $\mathrm{pH}$ of 8.4 , electrical conductivity of $0.51 \mathrm{mS} \mathrm{cm}^{-1}$ and an organic matter content of $1.2 \%$ in experiment III; and $58.2 \%$ sand, $36.6 \%$ clay, and $5.2 \%$ silt with a $\mathrm{pH}$ of 8.6 , electrical conductivity of $0.46 \mathrm{mS} \mathrm{cm}^{-1}$ and an organic matter content of $2.3 \%$ in experiment IV. Five different treatments were tested against bacterial infections in both greenhouses: (i) untreated control; (ii) solarization with a 55- $\mu$ m-thick smoky gray photoselective LDPE film (Agriplast), obtained with addition of lampblack; (iii) solarization with a $25-\mu$ m-thick green coextruded film (Agriplast); (iv) solarization with a $25-\mu \mathrm{m}$ thick clear LDPE film (Agriplast); and (v) solarization with a 25- $\mu \mathrm{m}$-thick clear polyamide-based film (Agriplast). The solarization treatments performed in both greenhouses were arranged in a RCBD with three replications. Each experimental plot was $3.7 \times 14.5 \mathrm{~m}$. Solarization treatments lasted from 27 June to 25 August 2012 (59 days). After the solarization period and film replacement, tomato seedlings, cultivar Mister
Red (Zeta Seeds) with indeterminate growth were transplanted on 8 September 2012 in both greenhouses. The amount of natural infections caused by phytopathogenic pseudomonads was evaluated on plant samples collected on 24 January 2013 at the end of cropping season.

\subsection{Pathogen detection and characterization}

The presence of phytopathogenic pseudomonads on symptomatic tomato plants was confirmed on eight plants for each plot by numerous isolation attempts of bacterial isolates onto artificial culture. Symptomatic tissue pieces were washed with tap water, surface disinfected in $1.2 \%$ aqueous solution of sodium hypochlorite $(\mathrm{NaOCl})$ for $1 \mathrm{~min}$, rinsed twice in sterile distilled water (SDW), and blotted on sterile paper towels. Then, small pieces were placed into culture tubes containing SDW, vortexed and loopfuls of plant tissue suspension were streaked onto plates of nutrient agar (NA, Oxoid, Basingstoke UK) and King's medium B (KB). Plates were incubated at $25^{\circ} \mathrm{C}$ for $48 \mathrm{~h}$. Single colonies that developed on the plates were purified and identified based on the LOPAT and Biolog analysis (Dimartino et al. 2011). In addition to Piccadilly, Ikram, Mister Red tomato cultivars transplanted in single greenhouse experiment, pathogenicity tests of a representative number of isolates were also carried out on cultivar Shiren (Cois 94).

\subsection{Disease assessment and tomato yield}

The effectiveness of treatments was determined by calculating disease incidence (DI) and severity of vascular infections (SS) at the end of the cropping season. To this aim, 16 to 26 plants were randomly selected from each plot, excluding border rows. An empirical 1-to-6 rating scale was used for $\mathrm{SS}$ evaluation, taking into account the length of discolored vascular tissues (Fig. 1 ), where $1=$ no symptoms; $2=$ up to $5 \mathrm{~cm} ; 3=5.1$ to $12 \mathrm{~cm} ; 4=12.1$ to $25 \mathrm{~cm} ; 5=25.1$ to $30 \mathrm{~cm}$; and 6 $=$ more than $30 \mathrm{~cm}$ length of infected vascular browning.

Yields in each plot were determined by the total weight (grams) of commercial tomato fruit per plant recorded during all the cropping season (cumulative harvests). Average yields per plant for each treatment were determined in all experiments.

\subsection{Statistical analysis}

STATISTICA package software (version 10; Statsoft Inc., Tulsa, OK, USA) was used for statistical analyses according to parametric or nonparametric approaches for randomized complete block design (RCBD). Effectiveness of soil solarization treatments (alone or 
combined with chemical or biological control means) in reducing bacterial infections and enhancing tomato yield was compared among different treatments including untreated controls. Means of DI, SS, and yield data for each treatment were calculated averaging values for each plot.

Initial analyses of DI and yield were conducted by calculating $\mathrm{F}$ and $p$ values associated for experiments performed in twin greenhouses (III and IV) to evaluate whether greenhouse covering $\times$ soil mulching interaction is significant.

Subsequently, analysis of variance (ANOVA) for a randomized complete block design was conducted on DI and yield data using post-hoc Fisher's least significant difference test at $\alpha=0.05$. Prior to analysis, percentage values were transformed as arcsine square root to improve homogeneity of variances, whereas untransformed arithmetic means of DI are shown in the Tables 1 and 2 .

Because an ordinal scale was adopted for bacterial infection severity, SS data were analyzed according to a nonparametric approach, i.e., Kruskal-Wallis one-way analysis followed by all possible pairwise comparisons using the Mann-Whitney test (Shah and Madden 2004).

\section{Results and discussion}

\subsection{Pathogen detection and characterization}

Bacteria were always isolated from the internal stem tissue of symptomatic tomato plants on NA and $\mathrm{KB}$ independently from examined plot and treatment thus indicating a widespread diffusion of bacterial infections on tomato during crop cycle thus confirming previous data on infection levels reported for this representative production area by Dimartino et al. (2011). All isolates were gram negative and fluorescent on $\mathrm{KB}$ medium. They always showed LOPAT characters of $\mathrm{Va}$ and $\mathrm{Vb}$ group according to Lelliott and Stead (1987). Using Biolog analysis, most part of the isolates was identified as $P$. fluorescens biovar 1, whereas P. fluorescens biovar IV and V and biovar A were rarely isolated. All bacterial isolates and $P$. fluorescens biovar 1 reference strain (CF2102) caused vascular discoloration symptoms on tomato seedlings on relative susceptible cultivars Piccadilly, Ikram, Mister Red and Shiren 14-20 days after inoculation. Re-isolated bacteria on $\mathrm{KB}$ were recognized as identical to the original strains by LOPAT scheme and Biolog analysis.

Table 1 Effects of soil solarization treatments in reducing natural infections caused by phytopathogenic pseudomonads and on relative yield of tomato in wooden-concrete and steel multi-span greenhouses respectively covered by EVA film with lateral openings kept raised in experiments I and II

\begin{tabular}{|c|c|c|c|c|c|}
\hline Treatment & DI $(\%)$ & SS (1-to-6 scale) & Rank mean & Rank sum & Yield (g/plant) \\
\hline \multicolumn{6}{|l|}{ I Experiment } \\
\hline Control & $56.7 \mathrm{a}$ & $2.07 \mathrm{~b}$ & 149.58 & 8975.0 & $1240.00 \mathrm{a}$ \\
\hline Smoky gray & $10.0 \mathrm{~b}$ & $1.10 \mathrm{a}$ & 98.65 & 5919.50 & $1313.33 \mathrm{ab}$ \\
\hline Green & $10.0 \mathrm{~b}$ & $1.17 \mathrm{a}$ & 99.58 & 5975.0 & $1286.67 \mathrm{ab}$ \\
\hline Green + Biofence & $12.73 \mathrm{~b}$ & $1.19 \mathrm{a}$ & 102.35 & 6346.0 & $1366.67 \mathrm{~b}$ \\
\hline Green + Trichoderma & $10.5 \mathrm{~b}$ & $1.13 \mathrm{a}$ & 99.12 & 5947.0 & $1320.00 \mathrm{ab}$ \\
\hline Green + Brassica pellet & $10.7 \mathrm{~b}$ & $1.27 \mathrm{a}$ & 100.62 & 6037.0 & $1303.33 \mathrm{ab}$ \\
\hline \multirow[t]{2}{*}{ EVA } & $3.3 \mathrm{c}$ & $1.03 \mathrm{a}$ & 92.21 & 5533.0 & $1376.67 \mathrm{~b}$ \\
\hline & $F=20.23 ; p<0.001$ & \multicolumn{3}{|c|}{$\chi^{2}=43.68 ; p<0.001$} & $p<0.001$ \\
\hline \multicolumn{6}{|l|}{ II Experiment } \\
\hline Control & 93.33 & 3.20 & 123.47 & 7408.0 & $2856.67 \mathrm{a}$ \\
\hline EVA & 76.67 & 3.07 & 116.45 & 6987.0 & $2900.00 \mathrm{a}$ \\
\hline $\mathrm{EVA}+$ metam-Na & 80.00 & 3.00 & 113.82 & 6829.0 & $3016.67 \mathrm{ab}$ \\
\hline $\mathrm{EVA}+$ metam-K & 73.33 & 2.93 & 112.95 & 6777.0 & $2960.00 \mathrm{ab}$ \\
\hline EVA + Biofence & 50.00 & 2.10 & 73.85 & 4431.0 & $3080.00 \mathrm{~b}$ \\
\hline EVA + Trichoderma & 63.33 & 2.60 & 97.75 & 5865.0 & $2850.00 \mathrm{a}$ \\
\hline \multirow[t]{2}{*}{ Green coextruded } & 64.17 & 2.50 & 92.41 & 5175.0 & $2870.00 \mathrm{a}$ \\
\hline & $F=1.00 ; p=0.46^{\mathrm{ns}}$ & \multicolumn{3}{|c|}{$\chi^{2}=11.98 ; p=0.062^{\mathrm{ns}}$} & $p=0.009$ \\
\hline
\end{tabular}

Data are means of three replicates (plots), each consisting of 16 to 22 tomato plants. Disease incidence (DI) and symptoms severity (SS) values followed by the same letters within a column are not significantly different according to the Fisher least significant difference test at $\alpha=0.01$ for DI and $\alpha=0.05$ for yield. Arcsine $\left(\sin ^{-1}\right.$ square root $x$ ) transformation was used on percentage data prior to analysis, whereas untransformed data are presented. Differences among rank sums of SS data for each treatment were analyzed with Kruskal-Wallis one-way analysis of variance by ranks $\left(\chi^{2}\right.$ value and $p$ values indicate the significance) followed by all pairwise multiple comparisons with Mann-Whitney test 
Table 2 Effects of soil solarization treatments in reducing natural infections caused by phytopathogenic pseudomonads and on relative yield on tomato in twin steel tunnel multi-span greenhouses (experiments III and IV), respectively covered by EVA and polyamide film, both kept closed throughout the whole experiment

\begin{tabular}{|c|c|c|c|c|c|}
\hline Treatment & DI $(\%)$ & SS (1-to-6 scale) & Rank mean & Rank sum & Yield (g/plan \\
\hline \multicolumn{6}{|l|}{ III Experiment } \\
\hline Control & $100.0 \mathrm{~b}$ & $4.73 \mathrm{~b}$ & 142.61 & 9412.0 & $2010.00 \mathrm{a}$ \\
\hline Smoky gray & $30.53 \mathrm{a}$ & $1.81 \mathrm{a}$ & 64.54 & 4647.0 & $2976.67 \mathrm{~b}$ \\
\hline Green & $51.51 \mathrm{a}$ & $2.06 \mathrm{a}$ & 74.61 & 4924.0 & $2756.67 \mathrm{~b}$ \\
\hline $\mathrm{PE}$ & $41.68 \mathrm{a}$ & $2.11 \mathrm{a}$ & 73.82 & 5315.0 & $2813.33 \mathrm{~b}$ \\
\hline \multirow[t]{2}{*}{ Polyamide VIF } & $49.39 \mathrm{a}$ & $2.06 \mathrm{a}$ & 74.52 & 4.772 .0 & $2780.00 \mathrm{~b}$ \\
\hline & $F=30.08 ; p<0.001$ & \multicolumn{3}{|c|}{$\chi^{2}=43.17 ; p<0.001$} & $p<0.001$ \\
\hline \multicolumn{6}{|l|}{ IV Experiment } \\
\hline Control & $94.45 \mathrm{~b}$ & $3.92 \mathrm{c}$ & 130.90 & 9425.0 & $2090.00 \mathrm{a}$ \\
\hline Smoky gray & $63.91 \mathrm{a}$ & $2.81 \mathrm{~b}$ & 99.35 & 7153.0 & $2720.00 \mathrm{~b}$ \\
\hline Green & $35.11 \mathrm{a}$ & $1.74 \mathrm{a}$ & 67.01 & 4557.0 & $2816.67 \mathrm{~b}$ \\
\hline $\mathrm{PE}$ & $34.85 \mathrm{a}$ & $2.03 \mathrm{a}$ & 72.90 & 5103.0 & $2933.33 \mathrm{~b}$ \\
\hline \multirow[t]{2}{*}{ Polyamide VIF } & $43.16 \mathrm{a}$ & $2.03 \mathrm{a}$ & 76.00 & 5624.0 & $2743.33 \mathrm{~b}$ \\
\hline & $F=10.34 ; p=0.001$ & \multicolumn{3}{|c|}{$\chi^{2}=42.90 ; p<0.001$} & $p<0.001$ \\
\hline
\end{tabular}

Data are means of three replicates (plots), each consisting of 20 to 26 tomato plants. Disease incidence (DI) and symptoms severity (SS) values followed by the same letters within a column are not significantly different according to the Fisher least significant difference test at $\alpha=0.01$ for DI and $\alpha=0.05$ for yield. Arcsine $\left(\sin ^{-1}\right.$ square root $\left.\mathrm{x}\right)$ transformation was used on percentage data prior to analysis, whereas untransformed data are presented. Differences among rank sums of SS data for each treatment were analyzed with Kruskal-Wallis one-way analysis of variance by ranks $\left(\chi^{2}\right.$ value and associated $p$ level indicate the significance) followed by all pairwise multiple comparisons with Mann-Whitney test

\subsection{Environmental conditions and soil temperatures}

During the four greenhouse experiments, environmental conditions were very similar as well as representative of the mean seasonal values for the areas where the studies were carried out. Throughout the duration of the solarization treatments, there were few cloudy days and no precipitation occurred. The mean value of the daily global solar radiation flux ranged from $23.1 \mathrm{MJ} \mathrm{m}^{-2}$ in experiment I to $24.4 \mathrm{MJ} \mathrm{m}^{-2}$ in experiment II, slightly higher than 24.3 obtained in experiments III and IV. Correspondingly, the mean value of daily global solar radiation inside the greenhouses ranged from $15.4 \mathrm{MJ} \mathrm{m}^{-2}$ in experiment I under the wooden-concrete greenhouse to $17.1 \mathrm{MJ} \mathrm{m}^{-2}$ in all the other three experiments under steel-framed greenhouses. Mean values of outside air temperature ranged from $24.8{ }^{\circ} \mathrm{C}$ in experiment I to $25.9{ }^{\circ} \mathrm{C}$ in experiment II, while in experiments III and IV it was $24.9^{\circ} \mathrm{C}$. Inside the greenhouses, the lowest value of mean air temperature $\left(32.0^{\circ} \mathrm{C}\right)$ was obtained in experiment II, whereas the highest values were obtained in experiments IV and III and they were $36.1{ }^{\circ} \mathrm{C}$ and $36.4{ }^{\circ} \mathrm{C}$, respectively. An intermediate value $\left(34.8^{\circ} \mathrm{C}\right)$ was obtained in experiment I. As regards the mean values of air relative humidity, outside the greenhouses it ranged from $61.1 \%$ in experiment II to $70.9 \%$ in experiment I, while in experiments III and IV it was $63.5 \%$. Inside the greenhouses the lowest mean values were obtained in experiments III and IV, respectively equal to
37.0 and $39.2 \%$, due to the combined effects of high air temperature and lack of ventilation. Higher values were obtained in experiment I (54.6\%) and experiment II (51.4\%).

In all experiments, the effect of mulching films in increasing the soil temperature was evident when compared with the control (bare soil). Specifically, the highest increase occurred in experiment III under polyamide mulch, with a maximum temperature increase equal to $9.6^{\circ} \mathrm{C}$ at $15 \mathrm{~cm}$ depth and $7.7^{\circ} \mathrm{C}$ at $30 \mathrm{~cm}$ depth. The number of hours during which the maximum soil temperature equaled or exceeded threshold values from 35 to $47.5^{\circ} \mathrm{C}$ is shown in Figs. 2 and 3. The results obtained are comparable with those obtained in other solarization treatments (Vitale et al. 2011, 2013a; Oz et al. 2017). Meaningful differences can be noticed in soil temperatures obtained in experiments I and II (Fig. 2) when compared with those ones obtained in experiments III and IV (Fig. 3). In detail, at $15 \mathrm{~cm}$ depth, in experiments III and IV temperature reached $47.5{ }^{\circ} \mathrm{C}$ in all mulched soil and it exceeded this threshold for more than $300 \mathrm{~h}$; at the same depth in experiment I temperature exceeded $47.5^{\circ} \mathrm{C}$ for an appreciable number of hours (243) only under EVA mulch, whereas in experiment II this threshold was exceeded again only by the EVA mulch, but for a very low number of hours (33). At $30 \mathrm{~cm}$ depth, temperature did not reach $47.5^{\circ} \mathrm{C}$ in any experiment. At the same depth, in experiments III and IV all the mulched soil reached $45{ }^{\circ} \mathrm{C}$ and this threshold was exceeded for more than $280 \mathrm{~h}$ under the green, 
a

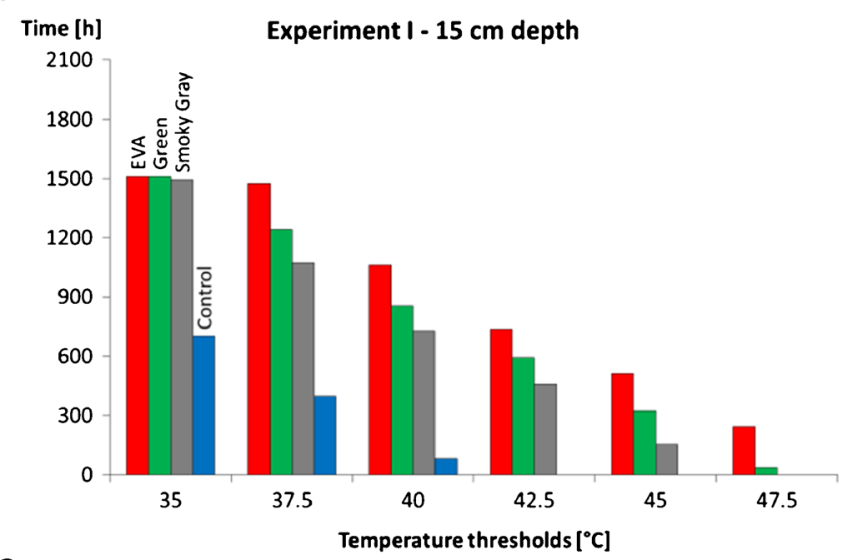

C

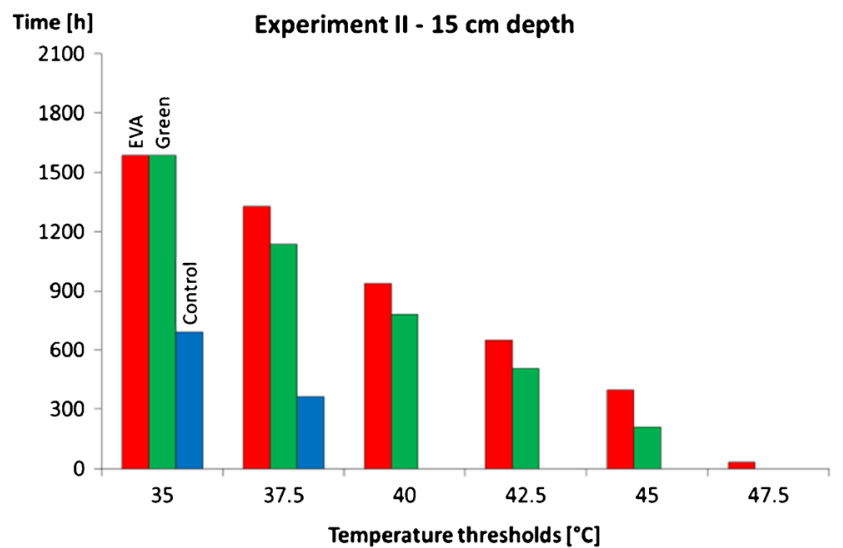

b

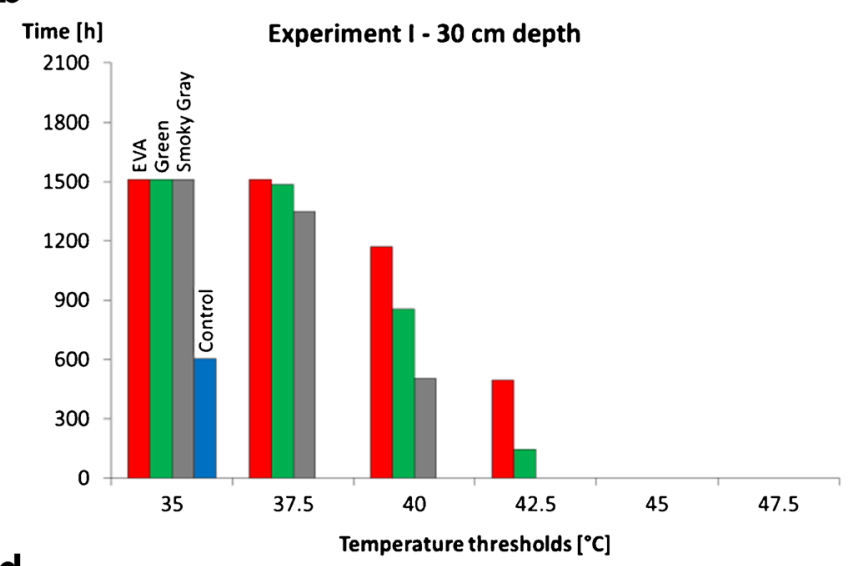

d

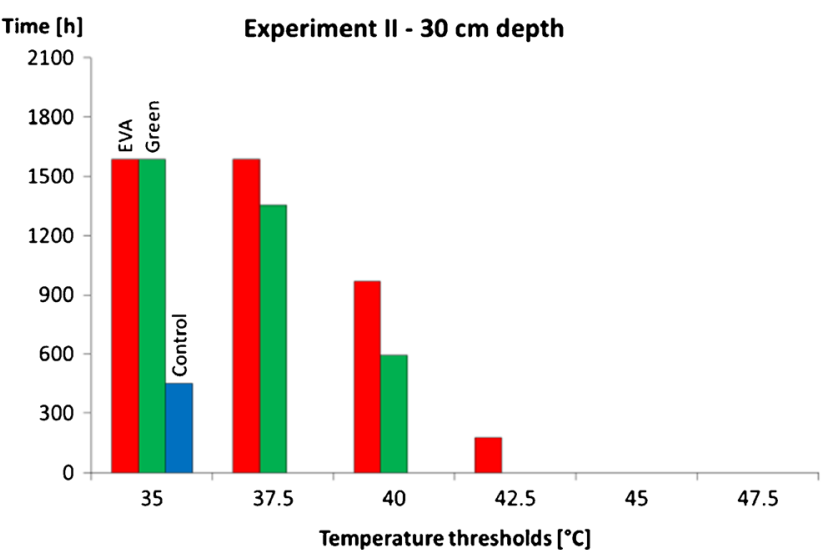

Fig. 2 Number of hours exceeding temperature thresholds at 15 and $30 \mathrm{~cm}$ depth during soil solarization performed in greenhouses with lateral openings partially kept raised (experiments I and II)

PE and polyamide mulch, whereas in experiments I and II soil temperature did not even reach $45^{\circ} \mathrm{C}$.

\subsection{Disease and tomato yield assessment}

The analysis of variance showed always a significant effect of all solarization treatments in reducing natural infections caused by phytopathogenic Pseudomonads on tomato crop under different greenhouse conditions (as indicated by $\chi^{2}, \mathrm{~F}$, and $p$ level) in experiments I, III, and IV except for experiment II where all soil treatments failed in managing bacterial infections (Tables 1 and 2). Inoculum survival reduction due to soil solarization was previously reported for phytopathogenic Pseudomonads on tomato (Moura et al. 2012). Recently, Wu et al. (2011) proposed large-scale application of solarization under closed greenhouses for soil inactivation of Escherichia coli into soil. However, the effects of this technique against bacteria were almost always evaluated only in microcosms or following artificial inoculation in soil under controlled environments.

Regard to the present study, in greenhouse experiments I and II performed under wooden-concrete and steel frame both with lateral openings kept raised, soil solarization treatments (alone or combined with other control measures) provided variable performances in reducing infections caused by phytopathogenic pseudomonads accordingly to sum of hours exceeding temperature threshold detected over two experiments and solarized plots. To this regard, it is useful to underline that the temperature sums above fixed threshold were slightly higher in experiment I than experiment II within plots mulched by the same film (Fig. 2). In addition, a moderate level of $P$. fluorescens infections was detected at the end of the tomato crop cycle in the untreated plots in experiment I. Under these conditions, the DI of infected plants and SS values were always significantly reduced in plots solarized with EVA, green and smoky gray film if compared with those of unsolarized controls. Comprehensively, EVA film provided the best results in DI reduction if compared to the other solarized plots, although $\mathrm{SS}$ values did not significantly differ from remaining treatments (Table 1). Otherwise, in the presence of higher level of infections detected in experiment II, all solarization treatments performed with EVA and green films and also including those combined with chemical or biological means, were not able to reduce significantly DI and SS of natural infections caused 

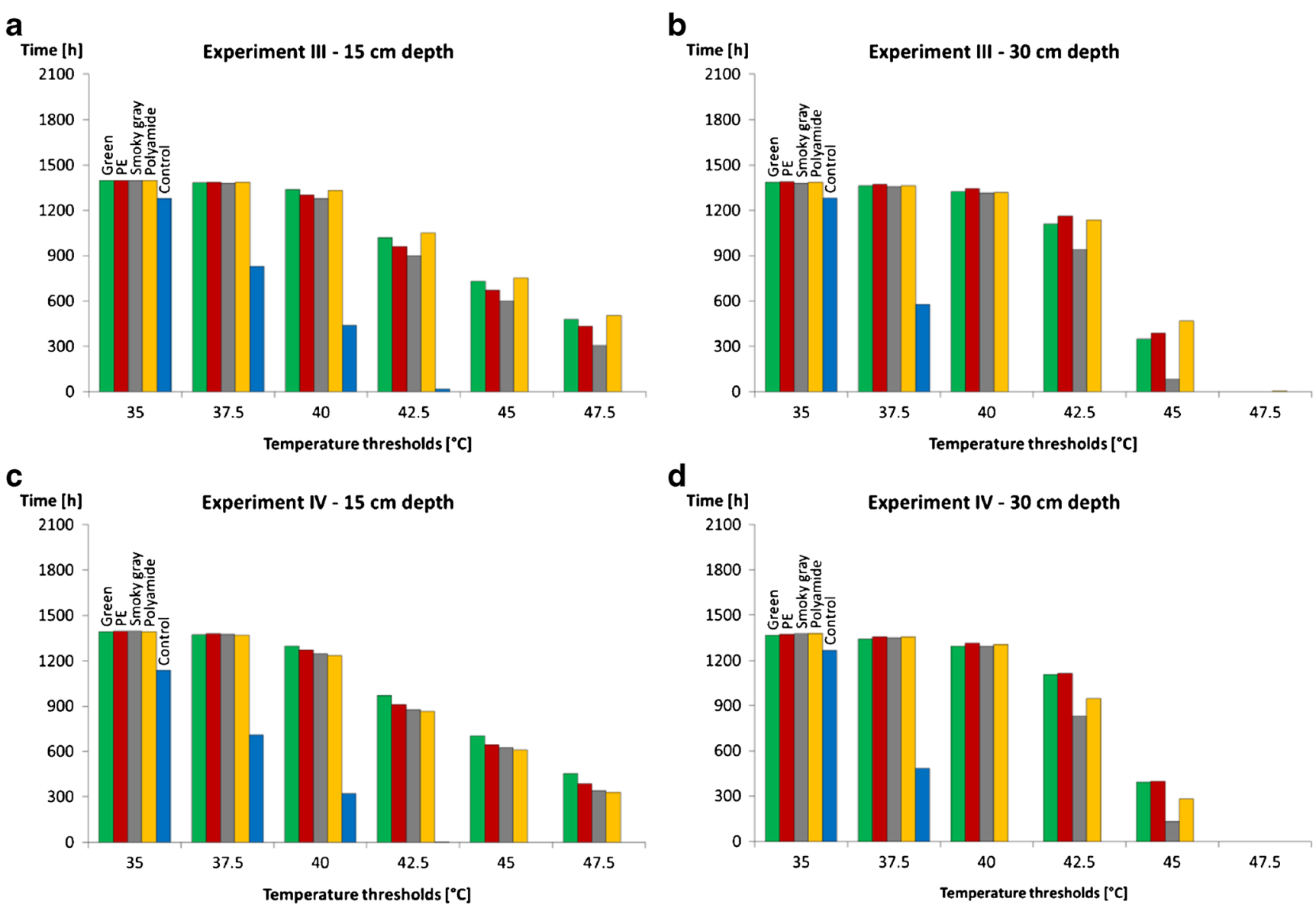

Fig. 3 Number of hours exceeding temperature thresholds at 15 and $30 \mathrm{~cm}$ depth during soil solarization performed in greenhouses with lateral openings hermetically closed (experiments III and IV)

by phytopathogenic Pseudomonads (Table 1). Besides to variable bacterial disease pressure over time across two experiments, data differences may be probably due also to the different greenhouse structures. Indeed, the wooden-concrete frame showed a high heat capacity and a low thermal diffusivity, so that it is able to storage heat and to release it during nighttime unlike the steel frame that tends to cool shortly after sunset. However, incorporation of biofertilizers or fumigant or BCAs application in combination with soil solarization did not improve the efficacy against bacterial infections if compared with solarization alone. Regarding tomato production, a significant increase of yield per plant (cultivar Piccadilly) was also recorded in solarized plots with EVA (about up to 11\%) and with coextruded green film combined with Biofence application (up to 10\%), respectively, in experiment I. On the other hand, the yield in remaining solarized plots did not significantly differ from the bare plots. Nevertheless, no significant differences were detected among all examined solarized plots (Table 1). Although no significant effect of soil treatment was recorded against Pseudomonads infections in experiment II as above reported, a significant yield increase on tomato cultivar Ikram was detected only in the plots simultaneously treated with Biofence and solarized with EVA (Table 1). Based on these specific results, soil treatments including fumigant application should be discouraged because they failed both in reducing bacterial infections and in enhancing yield of tomato crop and, moreover, for environmental reasons. Comprehensively, these data could be probably due to the highest film performances against bacterial infections as well as to a positive effect as a soil fertilizer of Biofence on tomato production.

Results of statistical analysis of disease incidence, symptoms severity and average tomato yield for experiments III and IV showed that greenhouse covering $\times$ soil treatment interaction was significant $(p<0.05)$. Therefore, the data on efficacy of treatments were analyzed for single experiment (by each greenhouse). The performances of mulching films in reducing natural infections caused by phytopathogenic Pseudomonads in experiments III and IV under steel-framed greenhouses, kept closed throughout the whole treatment and covered with EVA and polyamide films, respectively, are shown in Table 2. Highest infection levels than those recorded in two previous experiments were detected on tomato crop as it is clearly indicated by DI and SS values detected on unsolarized plots. Under these phytosanitary conditions, solarization treatments always reduced significantly infections caused by phytopathogenic 
Pseudomonads and simultaneously increased the average tomato yield. However, some differences about ranking of film performances in reducing natural infections were detected over the two experiments. Inside greenhouse covered with EVA film (experiment III), post-hoc analyses and all pairwise combinations between soil mulching films revealed that the DI and SS values were always significantly lower in plots solarized with smoky gray, green, PE, and polyamide film relative to the bare plots while no differences were detected among tested solarization treatments. In experiment IV, under the greenhouse covered with polyamide film, statistical analysis showed a similar effectiveness ranking in bacterial disease control except for the comparison of SS values between plots solarized with smoky gray film and the remaining films (green, PE, and polyamide VIF), whose performances were significantly higher. These results are in accordance with the thermal regimes achieved in the solarized soil under the various mulches in each greenhouse especially at $30 \mathrm{~cm}$ depth (Fig. 3). Indeed, soil temperature under the smoky gray film were slightly lower than under the other films due to its low solar transmittance, which is not enough counterbalanced by its opacity to thermal radiation (Cascone et al. 2012). However, these slight thermal differences produced significant effects only for SS variable in the experiment IV (Table 2). The effect of soil solarization with different mulching films always induced significant tomato yield increases ranging from 37.1 to $48.1 \%$ and from 30.1 to $40.33 \%$ relative to the bare plots in experiment III and IV, respectively (Table 2).

Comprehensively, this paper shows that soil solarization with innovative films effectively managed bacterial infections of tomato caused by phytopathogenic pseudomonads under greenhouse conditions and the technique would be compatible with normal agronomic practices developed for tomato production under protected crops. Among the tested films, the use of green film could be particularly attractive because it can be left on after the solarization period as mulch for extended weed control and increased soil temperature during earlyseason root development thus confirming and implementing the findings obtained in a previous paper for other soilborne pathogen (Vitale et al. 2011). In addition, the use of new materials for soil mulching or greenhouse covering could allow the reduction of plastic consumption since these films can be used for more crop cycles (e.g., polyamide) and, at the same time, they maintain the same performances of traditional materials film against soilborne pathogens.

\section{Conclusion}

Up to nowadays, studies on solarization effects against natural infections caused by phytopathogenic bacteria are scarce and this technique is largely applied against soilborne fungi, nematodes and weeds (Gamliel and Katan 2012). To our knowledge, this paper represents the first evidence of the large-scale effects of soil solarization under different operative conditions, including greenhouse structures (from wood and concrete to steel-framed structure), operative conditions (closed or partially opened greenhouse), and new plastic materials against natural infections caused by phytopathogenic bacteria on tomato. Soil solarization carried out with traditional and innovative films for at least 8 -week period in closed greenhouses was able to both manage bacterial infections by phytopathogenic Pseudomonads and, at the same time, to increase tomato yield. Under these conditions, no applications of biofertilizers or BCAs or low fumigant rates are required to improve phytosanitary and/or agronomic performances of solarization. This technique could be also applied in presence of moderate disease levels under partially open greenhouse. Consequently, it could represent a feasible and sustainable option for growers in the Mediterranean basin for the management of these more expanding threats for tomato crops.

Acknowledgements Alessandro Vitale who conceived the research and finalized this paper acknowledges Prof. Giancarlo Polizzi for the precious suggestions to improve this study and for contributing the laboratory and analysis tools and $\mathrm{PhD}$. Maria Dimartino for technical assistance in greenhouse trials.

Author contributions Ivana Castello carried out greenhouse and laboratory activities regarding phytopatological and agronomic aspects and wrote the relative sections in the paper draft, Alessandro D'Emilio carried out greenhouse activities referred to measurement of environmental parameters and soil temperature regimes and wrote the relative sections in the paper draft, Michael Raviv critically read and improved the manuscript draft, Alessandro Vitale designed the research, participated and supervised all experimental activities, analyzed and interpreted the data, and wrote, revised, and provided the final manuscript version. All authors read and approved the final manuscript.

Funding Statement Funding for this work was in part provided by PROM Research Project "Potenziare la Competitività di Orticole in Aree Meridionali" financed by CRA, by FIR project_2014 "Sustainable approaches for soil and substrate disinfestation against soilborne pathogens," and by Di3A Research Project 2016-2018 "Emergent Pests and Pathogens and Relative Sustainable Strategies-5A722192112" financed by University of Catania.

\section{References}

Barredo JI, Caudullo G, Dosio A (2016) Mediterranean habitat loss under future climate conditions: assessing impacts on the Natura 2000 protected area network. Appl Geogr 75:83-92. https://doi.org/10. 1016/j.apgeog.2016.08.003

Bebber DP (2015) Range-expanding pests and pathogens in a warming world. Annu Rev Phytopathol 53:335-356. https://doi.org/10.1146/ annurev-phyto-080614-120207

Bradbury JF (1986) Guide to plant pathogenic bacteria. CAB International Mycological Institute, Kew

Cascone G, D'Emilio A, Buccellato E, Mazzarella R (2008) New biodegradable materials for greenhouse soil mulching. Acta Hortic 801: 283-290. 10.17660/ActaHortic.2008.801.28

Cascone G, D'Emilio A, Mazzarella R (2012) Polyamide-based film as greenhouse covering in soil solarization. Acta Hortic 927:659-666. 10.17660/ActaHortic.2012.927.81 
Chellemi DO (2002) Nonchemical management of soilborne pests in fresh market vegetable production systems. Phytopathology 92: 1367-1372. https://doi.org/10.1094/PHYTO.2002.92.12.1367

D’Emilio A, Mazzarella R, Porto SMC, Cascone G (2012) Neural networks for predicting greenhouse thermal regimes during soil solarization. Trans ASABE 55:1093-1103. 10.13031/2013.41503

Dimartino M, Panebianco S, Vitale A, Castello I, Leonardi C, Cirvilleri G, Polizzi G (2011) Occurrence and pathogenicity of Pseudomonas fluorescens and P. putida on tomato plants in Italy. J Plant Pathol 93: 79-87. https://doi.org/10.4454/jpp.v93i1.276

Gamliel A, Katan J (2012) Soil Solarization: theory and practice. American Phytopathological Society, St. Paul, p 266 ISBN: 9780890544181

Gamliel A, Austerweil M, Kritzman G (2000) Non-chemical approach to soilborne pest management-organic amendments. Crop Prot 19: 847-853. https://doi.org/10.1016/S0261-2194(00)00112-5

Garrett KA, Dobson ADM, Kroschel J, Natarajan B, Orlandini S, Tonnang HEZ, Valdivia C (2013) The effects of climate variability and the color of weather time series on agricultural diseases and pests, and on decisions for their management. Agric For Meteorol 170:216-227. https://doi.org/10.1016/j.agrformet.2012.04.018

Gullino ML, Camponagara A, Gasparrini G, Rizzo V, Clini C, Garibaldi A (2003) Replacing methyl bromide for soil disinfestation - the Italian experience and implications for other countries. Plant Dis 87:1012-1021. https://doi.org/10.1094/PDIS.2003.87.9.1012

ISTAT (Istituto Nazionale di Statistica) (2016). Tavola C34-Superficie (are) e produzione (quintali): melanzana, popone o melone, peperone, pomodoro, zucchina-Ortaggi in serra http://agri.istat.it/ sag_is_pdwout/jsp/dawinci.jsp?q=plC340000010000011000\&an= 2016\&ig=1\&ct=329\&id=15A|18A|41A

Lelliott RA, Stead DE (1987) Methods for the diagnosis of bacterial diseases of plants. Blackwell Scientific Publications, Oxford

Lo Cantore P, Iacobellis NS (2002) Necrosi corticale e del midollo del pomodoro causata da Pseudomonas fluorescens in Puglia. Inf Fitopatol 4:54-57

Mauro RP, Lo Monaco A, Lombardo S, Restuccia A, Mauromicale G (2015) Eradication of Orobanche/Phelipanche spp. seedbank by soil solarization and organic supplementation. Sci Hortic 193:62-68. https://doi.org/10.1016/j.scienta.2015.06.038

Melero-Vara JM, López-Herrera CJ, Basallote-Ureba MJ, Prados-Ligero AM, Vela MD, Macías FJ, Flor-Peregrín E, Talavera M (2012) Use of poultry manure combined with soil solarization as a control method for Meloidogyne incognita in carnation. Plant Dis 96:990-996. https://doi.org/10.1094/PDIS-01-12-0080-RE

Molan Y, Ibrahim Y (2007) First report of tomato (Lycopersicon esculentum) pith necrosis caused by Pseudomonas fluorescens and P. corrugata in the Kingdom of Saudi Arabia. Plant Dis 91:110. https://doi.org/10.1094/PD-91-0110B

Moura L, Queiroz I, Mourão I, Brito LM, Duclos J (2012) Survival and genotypic variation of Pseudomonas corrugata and $P$. mediterranea in response to soil solarization and biofumigation. Acta Hortic 933: 553-558. 10.17660/ActaHortic.2012.933.72

Oz H, Coskan A, Atilgan A (2017) Determination of effects of various plastic covers and biofumigation on soil temperature and soil nitrogen form in greenhouse solarization: new solarization cover material. J Polym Environ 25(2):370-377. https://doi.org/10.1007/ s10924-016-0819-y

Savary S, Nelson A, Sparks AH, Willocquet L, Duveiller E, Mahuku G, Forbes G, Garrett KA, Hodson D, Padgham J, Pande S, Sharma M, Yuen J, Djurle A (2011) International agricultural research tackling the effects of global and climate changes on plant diseases in the developing world. Plant Dis 95:1204-1216. https://doi.org/10.1094/ PDIS-04-11-0316

Saygili H, Aysan Y, Sahin F, Ustun N, Mirik M (2004) Occurrence of pith necrosis caused by Pseudomonas fluorescens on tomato plants in Turkey. Plant Pathol 53:803. https://doi.org/10.1111/j.1365-3059. 2004.01092.x

Shah DA, Madden LV (2004) Nonparametric analysis of ordinal data in designed factorial experiments. Phytopathology 94:33-43. https:// doi.org/10.1094/PHYTO.2004.94.1.33

Vitale A, Castello I, Cascone G, D’Emilio A, Mazzarella R, Polizzi G (2011) Reduction of corky root infections on greenhouse tomato crops by soil solarisation in south Italy. Plant Dis 95:195-201. https://doi.org/10.1094/PDIS-06-10-0418

Vitale A, Castello I, D’Emilio A, Mazzarella R, Perrone G, Epifani F, Polizzi G (2013a) Short-term effects of soil solarization in suppressing Calonectria microsclerotia. Plant Soil 368:603-617. https://doi. org/10.1007/s11104-012-1544-5

Vitale A, Crous PW, Lombard L, Polizzi G (2013b) Calonectria diseases on ornamental plants in Europe and the Mediterranean basin: an overview. J Plant Pathol 95:463-476. https://doi.org/10.4454/JPP.V95I3.007

Vitale A, Rocco M, Arena S, Giuffrida F, Cassaniti C, Scaloni A, Lomaglio T, Guarnaccia V, Polizzi G, Marra M, Leonardi C (2014) Tomato susceptibility to Fusarium crown and rot root: effect of grafting combination and proteomic analysis of tolerance expression in the rootstock. Plant Physiol Biochem 83:207-216. https:// doi.org/10.1016/j.plaphy.2014.08.006

Wu S, Nishihara M, Kawasaki Y, Yokoyama A, Matsuura K, Koga T, Ryuda N, Ueno D, Inoue K, Someya T (2011) Soil solarization in a greenhouse for controlling fecal contamination. Environ Control Biol 49:185-191. https://doi.org/10.2525/ecb.49.185

Zhang LX, Li SS, He T, Tan GJ (2014) Identification and pathogenicity of Pseudomonas fluorescens associated with canker disease of kiwifruit in central China. J Hortic Sci Biotechnol 89:130-135. https:// doi.org/10.1080/14620316.2014.11513058

Zhang C, Lin T, Li J, Ma G, Wang Y, Zhu P, Xu L (2016) First report of the melon stem rot disease in protected cultivation caused by Pseudomonas fluorescens. J Plant Dis Prot 123:247-255. https:// doi.org/10.1007/s41348-016-0030-3 